\title{
SYSTEMIC PLANNING (SP): A GENERIC FRAMEWORK FOR COMPLEX DECISION MAKING
}

\author{
Author(s) / Auteur(s) : \\ Steen LELEUR \\ Professor, dr.techn. \\ Technical University of Denmark, Department of Management Engineering \\ $\underline{\text { stle@dtu.dk }}$
}

\begin{abstract}
Résumé :
The generic framework for planning and decision support presented in this paper and referred to as systemic planning (SP) is the result of research work carried out by the Decision Modelling Group at the Technical University of Denmark (DTU). More specifically, SP theory and methodology development has interchanged with practical application and testing of SP in a number of cases. SP is based on combining and operationalising five different systems thinking approaches: functional, interpretive, emancipatory, post-modern and complexity-oriented that are seen to span current systems thinking. These approaches are behind five formulated modes of enquiry (MOEs) that make up some of the iteratively interwoven steps in a formulated SP process, which is assisted by a study-specific subset of methods. These are selected from a toolbox of seven soft (qualitative) and seven hard (quantitative) operations research (OR) methods.

The paper is disposed as follows: After an introduction that outlines the five systems thinking approaches and their MOEs, the paper presents SP in an overview as concerns process and tools and SP as a group proces. Then follows an application example where the potential of SP is demonstrated on the planning of a large transport infrastructure case concerning the Rail Baltica transport project, which is part of the EU's North SeaBaltic TEN-T corridor. The case shows how issues around growth and sustainability need to be explicitly considered in the planning of large new transport infrastructure. Finally, following a discussion of the main features of SP, some findings and a perspective are stated.
\end{abstract}

Keywords / Mots-clés :

systemic planning, complex decision making, group-based decision support, EU TEN-T corridor case Rail Baltica, growth and sustainable development

\section{INTRODUCTION}

Systems thinking as a reflected activity dates back at least to the 1920s (Bertalanffy, 1973). Its onward development can be categorised as three waves with the third wave perceived as still unfolding, see Table 1 (Leleur 2012, 2014). Altogether five different approaches of systems thinking are shown with a number of features characterising each particular approach.

This table can be seen as an expression of the richness of enquiry contained in current systems thinking. The features range a large variety of possible types of exploration and examination across the five approaches and thereby they provide the systems practitioners with a very wide range of possibilities to design and develop a specific intervention or study. In practice, the outlined features below each approach aim to convey a mind-setting function in group deliberations (see later) by inducing a specific explorative discourse/ discussion domain.

Although the five approaches have appeared as successive developments in systems thinking with 'functional' as the most early and 'complexity-oriented' as the most recent it makes sense to see them generally as equally relevant as each one may in principle contribute to useful insights as regards a particular study context and purpose. Having recognised this it is, however, not surprising that certain types of problems will often draw to a higher extent on one or a few of the approaches. Thus the relevance of each approach for a study or intervention will depend on the actual task and its context (Midgley, 2000) (Jackson 2000, 2003) (Stowell and Welsh, 2012) and (Leleur, 2012, 2017). 
Table 1. Current five approaches of systems thinking

\begin{tabular}{|c|c|c|c|c|c|}
\hline $\begin{array}{l}\text { Systems } \\
\text { thinking as }\end{array}$ & $\begin{array}{l}1^{\mathrm{ST}} \text { WAVE } \\
1920 \text { s onwards }\end{array}$ & $\begin{array}{l}2^{\mathrm{ND}} \text { WAVE } \\
1970 \mathrm{~s} \text { onwards }\end{array}$ & \multicolumn{3}{|c|}{$\begin{array}{l}\text { 3RD WAVE - STILL UNFOLDING ... } \\
\text { 1990s onwards }\end{array}$} \\
\hline $\begin{array}{l}\text { Approach } \\
\text { VS. } \\
\text { Features }\end{array}$ & $\begin{array}{l}\text { FUNCTIO- } \\
\text { NALIST }\end{array}$ & $\begin{array}{l}\text { INTERPRE- } \\
\text { TIVE }\end{array}$ & $\begin{array}{l}\text { EMANCI- } \\
\text { PATORY }\end{array}$ & $\begin{array}{l}\text { POST- } \\
\text { MODERN }\end{array}$ & $\begin{array}{l}\text { COMPLEXITY } \\
- \text { ORIENTED }\end{array}$ \\
\hline BASIC GOAL & $\begin{array}{l}\text { Demonstrate } \\
\text { law-like } \\
\text { relations among } \\
\text { objects }\end{array}$ & $\begin{array}{l}\text { Display unified } \\
\text { culture }\end{array}$ & $\begin{array}{l}\text { Unmask } \\
\text { domination }\end{array}$ & Reclaim conflict & $\begin{array}{l}\text { Explore unknown } \\
\text { territory }\end{array}$ \\
\hline METHOD & $\begin{array}{l}\text { Nomothetic } \\
\text { science }\end{array}$ & $\begin{array}{l}\text { Hermeneutics, } \\
\text { ethnography }\end{array}$ & $\begin{array}{l}\text { Cultural and } \\
\text { ideological } \\
\text { critique }\end{array}$ & $\begin{array}{l}\text { Deconstruction, } \\
\text { genealogy }\end{array}$ & $\begin{array}{l}\text { Integrate } \\
\text { complexity and } \\
\text { simplicity } \\
\text { thinking }\end{array}$ \\
\hline HOPE & $\begin{array}{l}\text { Efficiency, } \\
\text { effectiveness, } \\
\text { survival and } \\
\text { adaptation }\end{array}$ & $\begin{array}{l}\text { Recovery of } \\
\text { integrative } \\
\text { values }\end{array}$ & $\begin{array}{l}\text { Reformation } \\
\text { of social order }\end{array}$ & $\begin{array}{l}\text { Claim a space } \\
\text { for lost voices }\end{array}$ & $\begin{array}{l}\text { Contingent } \\
\text { insights that will } \\
\text { mean 'a } \\
\text { difference' }\end{array}$ \\
\hline $\begin{array}{l}\text { ORGANISA- } \\
\text { TION } \\
\text { METAPHOR }\end{array}$ & $\begin{array}{l}\text { Machine, } \\
\text { organism, brain, } \\
\text { flux and } \\
\text { transformation }\end{array}$ & $\begin{array}{l}\text { Culture, } \\
\text { political system }\end{array}$ & $\begin{array}{l}\text { Psychic } \\
\text { prison, } \\
\text { instruments of } \\
\text { domination }\end{array}$ & Carnival & $\begin{array}{l}\text { The panopticon } \\
\text { with a restricted } \\
\text { view }\end{array}$ \\
\hline $\begin{array}{l}\text { PROBLEMS } \\
\text { ADDRESSED }\end{array}$ & $\begin{array}{l}\text { Inefficiency, } \\
\text { disorder }\end{array}$ & $\begin{array}{l}\text { Meaningless- } \\
\text { ness, } \\
\text { illegitimacy }\end{array}$ & $\begin{array}{l}\text { Domination, } \\
\text { consent }\end{array}$ & $\begin{array}{l}\text { Marginalization, } \\
\text { conflict } \\
\text { suppression }\end{array}$ & $\begin{array}{l}\text { Open-ended, } \\
\text { wicked and } \\
\text { hypercomplex } \\
\text { problems }\end{array}$ \\
\hline $\begin{array}{l}\text { NARRATIVE } \\
\text { STYLE }\end{array}$ & $\begin{array}{l}\text { Scientific/ } \\
\text { technical, } \\
\text { strategic } \\
\end{array}$ & $\begin{array}{l}\text { Romantic, } \\
\text { embracing }\end{array}$ & $\begin{array}{l}\text { Therapeutic, } \\
\text { directive }\end{array}$ & $\begin{array}{l}\text { Ironic, } \\
\text { ambivalent }\end{array}$ & $\begin{array}{l}\text { Multidimensio- } \\
\text { nal, eclectic }\end{array}$ \\
\hline $\begin{array}{l}\text { TIME } \\
\text { IDENTITY }\end{array}$ & Modern & Premodern & Late modern & Postmodern & Hypermodern \\
\hline $\begin{array}{l}\text { ORGANISATI- } \\
\text { ONAL } \\
\text { BENEFITS }\end{array}$ & $\begin{array}{l}\text { Control, } \\
\text { expertise }\end{array}$ & $\begin{array}{l}\text { Commitment, } \\
\text { quality of work } \\
\text { life }\end{array}$ & $\begin{array}{l}\text { Participation, } \\
\text { expanded } \\
\text { knowledge } \\
\end{array}$ & $\begin{array}{l}\text { Diversity, } \\
\text { creativity }\end{array}$ & $\begin{array}{l}\text { Awareness, } \\
\text { alertness }\end{array}$ \\
\hline MOOD & Optimistic & Friendly & Suspicious & Playful & Curious \\
\hline SOCIAL FEAR & Disorder & $\begin{array}{l}\text { Depersonali- } \\
\text { zation }\end{array}$ & Authority & $\begin{array}{l}\text { Totalization, } \\
\text { normalization }\end{array}$ & $\begin{array}{l}\text { Constrained } \\
\text { reasoning and } \\
\text { living }\end{array}$ \\
\hline
\end{tabular}

Altogether the five approaches lay the foundation for the holistic approach operationalised as systemic planning (SP), which due to its adaptability and flexibility is behind seeing SP generally as a generic framework for planning and decision support not suited solely to appraisal of major transport infrastructure projects. Such projects were the initial testbed for the related research work carried out by the Decision Modelling Group at the Technical University of Denmark (DTU) over the last ten years, but several case applications over the years (Leleur, 2012, 2017) have shown a wider scope for the application of SP.

The aim of this paper is to present SP as a worthwhile generic approach to make use of when facing complex strategic planning problems. At the core of making use of SP (with S for 'systemic') is that in a world being still more complex and uncertain strategic planning is in need of systemic insights in balance with more conventional, systematic findings. 


\section{THE SP PROCESS IN OVERVIEW}

SP is characterised by using the five systems approaches in Table 1 as a backdrop for five basic modes of enquiry (MOEs) that together form a holistic approach to complex problem handling. Their specific aims in this respect are set out below:

MOE 1: FUNCTIONAL aiming at improving goal seeking and viability

MOE 2: INTERPRETIVE aiming at exploring purposes

MOE 3: EMANCIPATORY aiming at ensuring fairness

MOE 4: POSTMODERN aiming at promoting diversity

MOE 5: COMPLEXITY aiming at exploring uncertain perceptions

With this background the following five SP MOEs in Table 2 serve to guide the exploration as concerns the methodology and process when applying SP for a complex planning problem. In Table 2 a linking of MOEs and hard and soft operations research (OR) methods has been indicated.

Table 2. The five modes of SP enquiry

\begin{tabular}{|c|c|}
\hline SP mode of enquiry (MOE): & Mainly involves the following OR methodology: \\
\hline CORE PERFORMANCE & Hard methodology \\
\hline WIDER PERFORMANCE & Hard and soft methodology \\
\hline FAIRNESS & Soft methodology \\
\hline DIVERSITY & Hard and soft methodology \\
\hline ROBUSTNESS & Hard and soft methodology \\
\hline
\end{tabular}

Based on case-experience the hard and soft OR methodology can draw on the methods in the SP toolbox in Table 3 below. Especially with messy problems soft OR methods can have an important role (Petkov et al., 2007).

Table 3. SP toolbox: Seven hard and seven soft system techniques and methods

\begin{tabular}{|c|c|}
\hline Hard methods & Soft methods \\
\hline $\begin{array}{c}\text { Cost-benefit analysis (CBA) } \\
\text { Analytic hierarchy process (AHP) } \\
\text { Simple multi-attribute rating technique } \\
\text { (SMART, SMARTER) }\end{array}$ & $\begin{array}{c}\text { Brainstorming (BS) } \\
\text { Sind mapping (MM) }\end{array}$ \\
\hline $\begin{array}{c}\text { Composite multi-criteria analysis (MCA), } \\
\text { COSIMA, SIMDEC } \\
\text { Scenario analysis (SA) } \\
\text { Preference analysis (PA) }\end{array}$ & Critical systems heuristics (CSH) \\
\hline Risk analysis based on Monte Carlo- \\
simulation (RA), SIMRISK
\end{tabular}

Several of the seven hard and seven soft techniques and methods are known well by systems practitioners but in case of method-info needed the references (Leleur, 2012, 2017) and (Leleur et al., 2015) may be consulted. Detailed information about the techniques and methods is available at www.systemicplanning.dk 
The toolbox aims at offering a not-too-large set of hard and soft methods for the use in various combinations in accordance with the way the SP process develops. As concerns the latter, Figure 1 below shows the SP process wheel that ties the examinations together: Step 1, 2 and 3 set the structure whereas Step 4, 5, 6, 7 and 8 concern the five MOEs. In Step 9 knowledge builds up towards decision making, and Step 1 in addition to initiating the process holds the possibility to restart a new round to reconsider relevant issues.

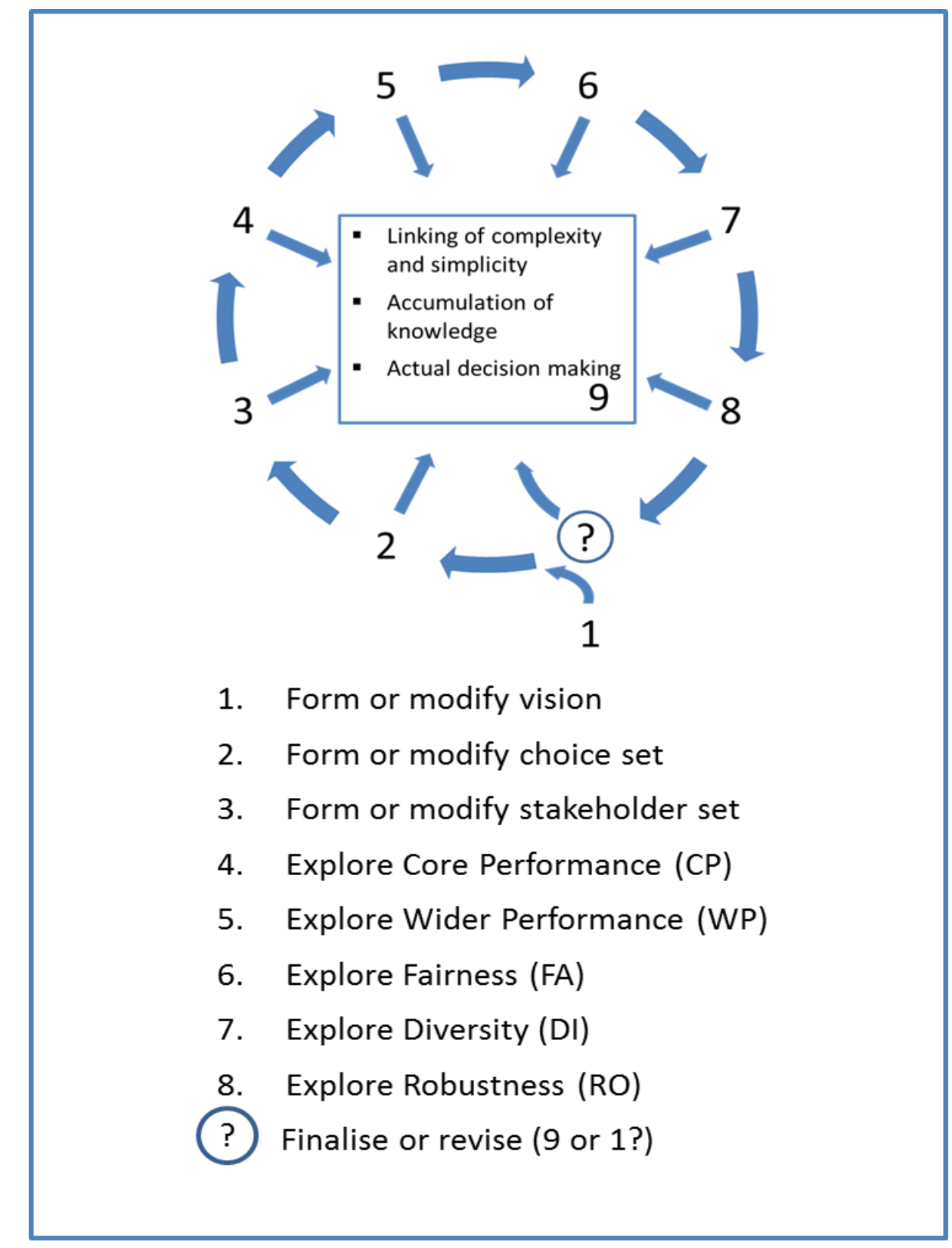

Figure 1. Overview of SP process wheel when dealing with a complex planning problem

As will appear from the application example described later the SP framework is highly flexible. Thus it can be adapted to the concrete circumstances of a specific complex decision problem. Furthermore, SP fits well into a group process where different visions and stakeholder views can be tested as concerns their influence on the actual decision making. SP as a group process is described below to be followed by a demo-example about rail infrastructure corridor planning. 


\section{THE SP PROCESS AS GROUP PROCESS}

Basically, the five systems approaches from Table 1 have been transformed into an integrated operational process that can be adapted to a particular complex planning problem by involving a group of people representative for defining and unfolding the planning vision, designing the choice set (possible courses of action as alternatives) and imposing stakeholder values. The main purpose and promise of SP is to provide the members of such an SP group with a kind of 'accelerated learning' about the planning problem. What qualifies this learning is that it is based on systems thinking perceived as unbounded and open-ended, see Table 1, which when duly transformed to become operational in SP can lead to structured deliberations that may or may not lead to a sufficient accumulation of decision knowledge, see Step 9 in Figure 1.

Evidently, the formation of the SP group is important and highly dependent on the actual problem and the interests involved. There can be no doubt that getting the 'right' members in the group matters. In this respect it should be observed based on experiences gained on SP testing and development over a decade that the membership should not depend on availability of particular skills about appraisal techniques as a facilitator and analyst support the process in a way so it can be followed by a participant without such qualifications. Figure 2 below shows an SP setting, which is similar in many ways to what is sometimes referred to as decision conference (DC). Less formally, the DC may be viewed as a planning workshop, where no decision is actually taken but which may end with a decision recommendation.

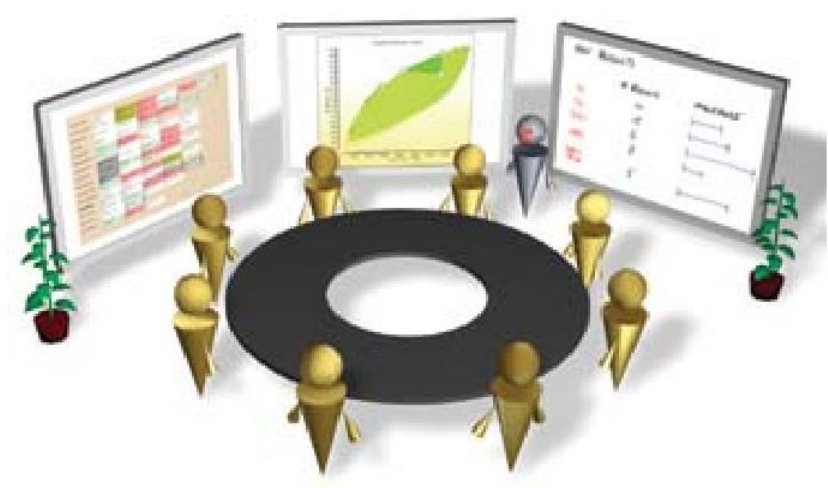

Figure 2. An illustration of the physical environment of a decision conference

Formally the decision conference can be considered as a design in which a creative and structured search-learn process can take place (Phillips, 2007). In practice, participants in the decision conference sit around a table with the fundamental aim to receive information, discuss the problem and give feedback to influence the upcoming activities. As already mentioned a facilitator guides the process, among other things by the use of interactive decision-support information technology. The assisting analyst takes input from the group based on the facilitator's various questions and models and displays the feedback to the group. In Figure 2 the plants shown next to the smartboards (which are used in combination with information technology and decision analysis software) underline symbolically that it is actually very beneficial if the physical environment of the decision conference/planning workshop is good. If the budget allows it, the conference should be held outside the organisation or company.

It is important for the quality of the decision conference that the facilitator opens the meeting by explaining the underlying theory of the decision modelling to be applied to the participants. In this way the participants will probably be more prone to accepting the subsequent model decisions based on different assessments when they have an idea of the methodology behind. However, as stated above 
the decision procedure is very intuitive so the participants need not have a full knowledge about the many theories and techniques used, but only about the basic knowledge presented as introduction.

The fundamental goal of using a decision conference/planning workshop as part of the SP approach is to create an assessment knowledge base from the insights and deliberations of the group. Ideally, this should lead to a common understanding or clarify any conflicts that need to be taken into consideration and dealt with. Furthermore, through their participation in the group process the participants should end up with a situation that can lead to agreement about a final decision or decision recommendation. The following section will describe a group-based application of SP.

\section{THE RAIL BALTICA CASE}

This example concerns a group-based application of SP for finding out which corridor alternative P1, P2 or P3 is best for a future upgraded railway connection, Rail Baltica, between Tallinn and Warsaw. This is a highly complex decision for a number of reasons: travel capacity and speed, societal impact, network standard, economy, sustainability. It can be noted that the planning of the corridor project, now in 2018 ready for implementation, has been carried out over the last decade and that the alternatives in the case represented three early and principally different design proposals. The three alternatives were made up as three investment packages presented in overview in Figure 3 below (Ambrasaite \& Leleur, 2014).

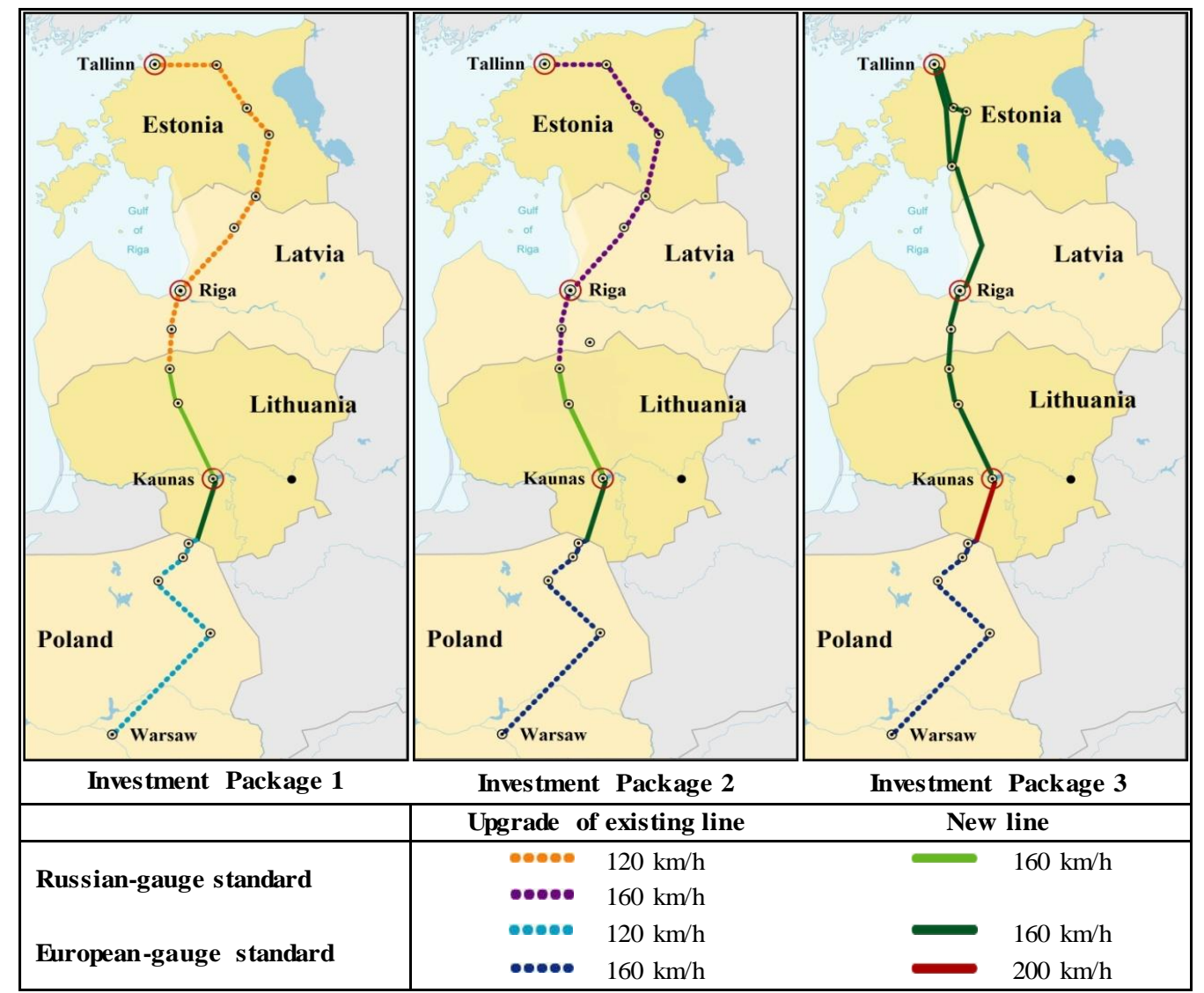

Figure 3. Three investment packages for Rail Baltica as corridor alternatives P1, P2 and P3

The SP group process in overview can be reiterated as follows: 
The first task for the group, see Step 1 in Figure 1, is to discuss possible visions that can underlie the further examination. Here the group deliberations ended up producing two different visions where one was a vision about pursuing a sustainable development and the other a vision about promoting economic growth and development.

The group referred to the two visions as Sustainable Development (SD) and Business-As-Usual (BAU), with SD reflecting an ongoing societal, still stronger demand and BAU an expression of a continued and more conventional societal demand.

The group considered both SD and BAU as important and wanted to see how the SD and BAU visions per se would influence the attractiveness of each of the three alternatives.

Step 2 in the SP process concerns the alternatives to make up the choice set. In this case the task was already defined to examine the three alternatives from the initial planning work. Thus the three investment packages in Figure 3 were accepted as input to Step 2.

Step 3 about formation of the stakeholder set, the last of the steps that initially structure the SP examination, put emphasis on securing that both SD-oriented and BAU-oriented representatives of these stakeholder views were present.

With Steps 4, 5, 6, 7 and 8 the SP modes of enquiry were focused upon, see Table 2.

Step 4 concerns Core Performance (CP): In general CP can be informed by examining maybe only one parameter seen as dominant and/or critical. In infrastructure planning this can e.g. for minor road improvements be carried out as simple cost-effectiveness analyses such as determining the amount of costs that are needed to save one statistically expected traffic accident; with lesser costs needed the road improvement becomes more attractive. With larger infrastructure investments such as the investment packages examined in this case, the $\mathrm{CP}$ can be treated as a cost-benefit analysis by calculating the benefit-cost ratios (BCRs). With the following investment costs for P1, P2 and P3 equal to EUR $\mathrm{m} \mathrm{979,} \mathrm{m} 1546$ and $\mathrm{m}$ 2369, the values in Table 4 were found indicating that the less costly alternative $\mathrm{P} 1$ had the best BCR value. Thus conventional decision making would indicate $\mathrm{P} 1$ as the most attractive. However, all three investment packages are feasible with a BCR higher than 1.00.

Table 4. The conventional BCR values for the three investment packages

\begin{tabular}{|l|ccc|}
\hline Alternatives & P1 & P2 & P3 \\
\hline $\begin{array}{l}\text { Benefit-cost ratios } \\
\text { (BCRs) }\end{array}$ & 2.92 & 2.65 & 2.27 \\
\hline
\end{tabular}

The issue now for the group was whether the other modes of enquiry would alter this CP-based ranking of alternatives. This is the purpose of Step 5 about Wider Performance (WP).

So far the group had applied brainstorming and cost-benefit analysis in their deliberations. In their further work about wider performance multi-criteria analysis was applied. Based on group deliberations and vision-interpretation the facilitator advised the group to make first a Long List of candidate criteria and then afterwards by scrutinising this list to set out a Short List of most important criteria. In doing so, they were assisted by the 'blue, green and orange' criteria shown in the sheet in Figure 4. The group was informed that it could also come up with criteria not shown in the sheet. 


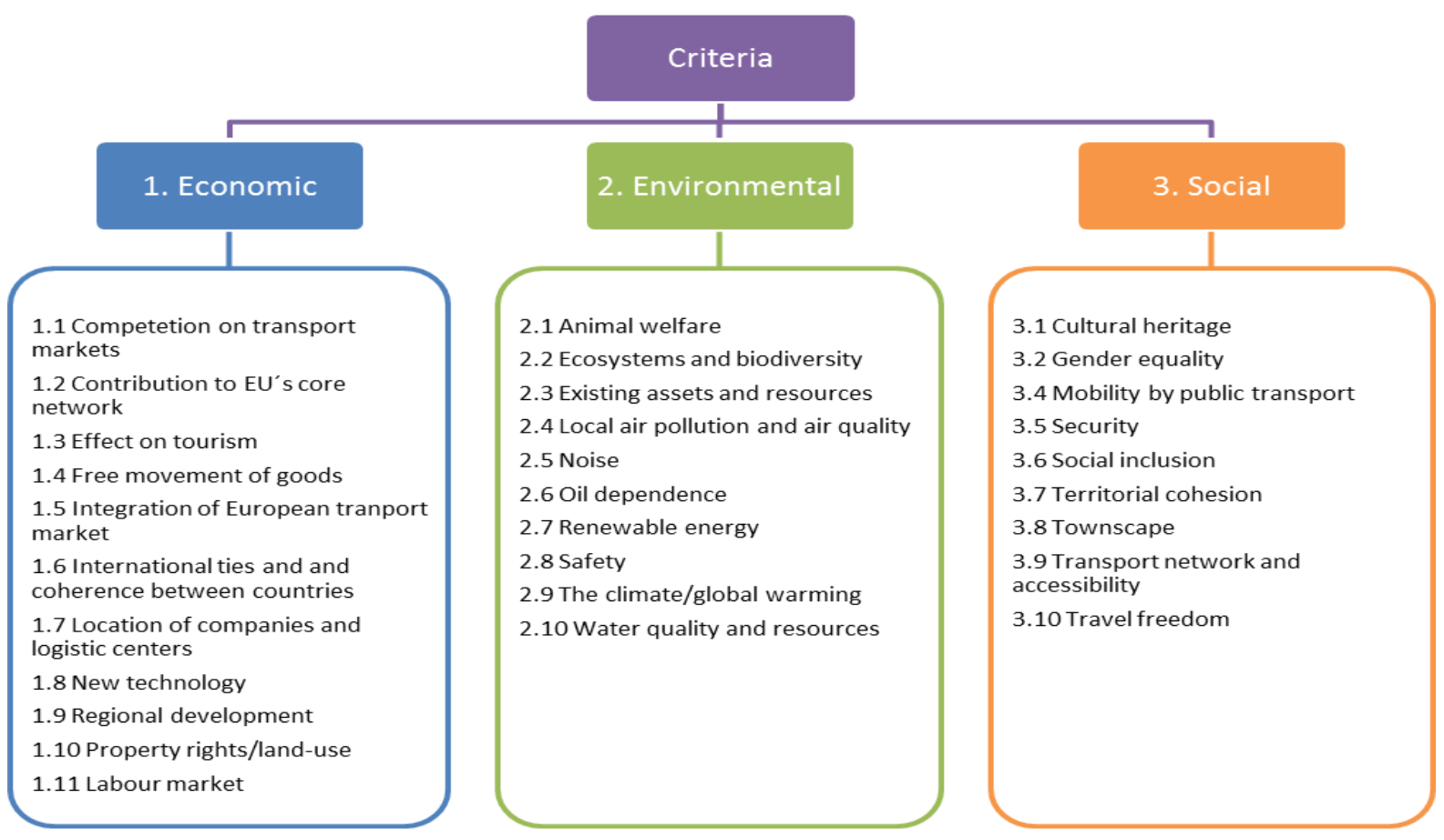

Figure 4. Criteria sheet applied to assist group deliberation about criteria selection

After having identified eight criteria all considered highly important as regards their desired influence on the ranking of alternatives, the group was asked to split into two, with one subgroup pursuing the BAU vision and the other the SD vision. Specifically, the SP facilitator asked each group to debate and rank the eight criteria under their respective vision.

The two short list rankings produced by each subgroup are shown in Table 5. Each criterion-rank in each of the two rankings is shown with a criterion-weight based on a weight approximation method known as Rank-Order-Distribution (ROD) weights, see (Ambrasaite \& Leleur, 2014). The use of ROD-weights is practical in group work as ranking of criteria appears to be easier to handle and agree upon than agreement about direct weight setting.

Table 5. SD and BAU ranking of short list criteria according to their vision-dependent importance. The derived RODweights are shown in parenthesis

\begin{tabular}{|l|l|l|}
\hline \multirow{2}{*}{ Criteria } & $\begin{array}{l}\text { Sustainability } \\
\text { SD vision/strategy } \\
\text { Ranking and (weight) }\end{array}$ & $\begin{array}{l}\text { Conventional } \\
\text { BAU vision/strategy } \\
\text { Ranking and (weight) }\end{array}$ \\
\hline Accessibility and transport networks & $2(0.20)$ & $4(0.14)$ \\
Promotion of EU's green corridors & $6(0.08)$ & $6(0.08)$ \\
Development of tourism & $7(0.05)$ & $5(0.11)$ \\
Impact on environment and ecology & $1(0.23)$ & $8(0.03)$ \\
Impact on health & $4(0.14)$ & $7(0.05)$ \\
Location and logistics of the company & $3(0.17)$ & $2(0.20)$ \\
Importance for regional development & $5(0.11)$ & $3(0.17)$ \\
Robustness with respect to socio-economics & $8(0.03)$ & $1(0.23)$ \\
\hline
\end{tabular}


As can be seen in Table 5 the SD vision and BAU vision produced different weights for the criteria, which will affect the overall attractiveness of each of the three alternatives under examination. At this stage it was important to perceive each vision as duly represented by the respective criteria and weights. In the actual case minor changes had to made before overall agreement was obtained about the results shown in Table 5. Next the multi-criteria technique known as analytic hierarchy process was applied to score each alternative under each criterion and finally to produce the total value of attractiveness as shown in Figure 5 (Ambrasaite \& Leleur, 2014).

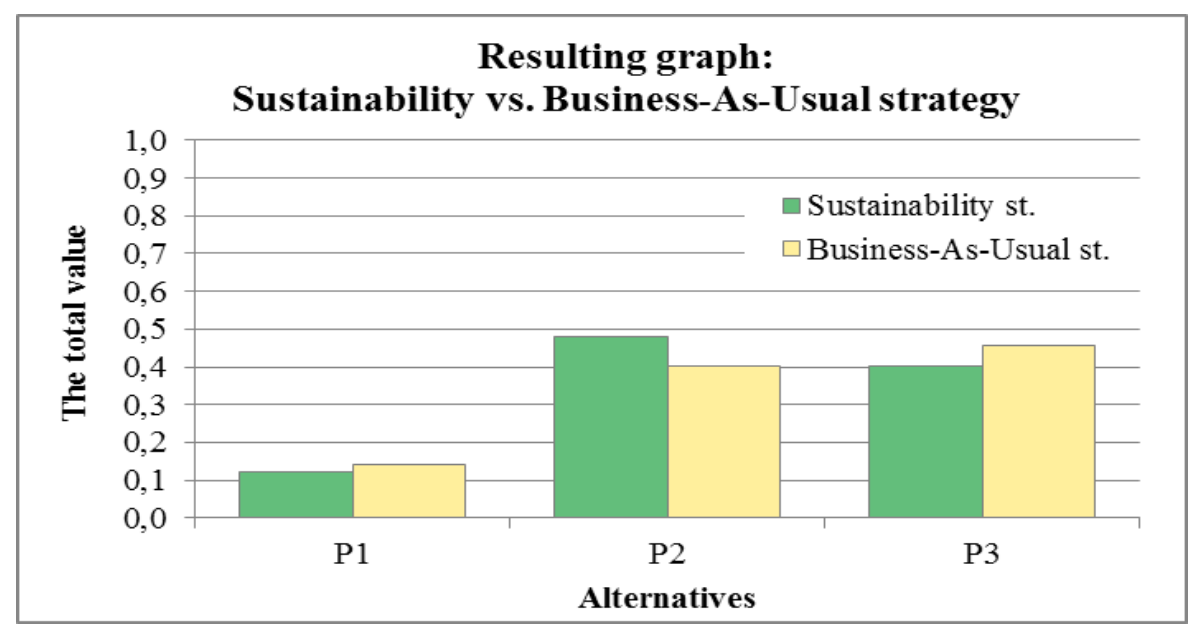

Figure 5. The Rail Baltica case results: With a BAU strategy P3 is the most attractive alternative, whereas P2 is the most attractive alternative when using an SD strategy

The results of Step 5 show that the ranking of the three alternatives from Table 4 changes when considering their wider performance. Under the SD vision P2 is now the most attractive while P3 is the most attractive under the BAU vision. Therefore, with a complex planning study such as the Rail Baltica a narrow CBA-based assessment representing the CP-ranking seems to be insufficient as both $\mathrm{P} 2$ and $\mathrm{P} 3$ reflect design qualities which per se are relevant under either the SD or the BAU vision.

The case reiterated here was carried out as part of a course at the Technical University of Denmark (Ambrasaite \& Leleur, 2014). As regards the Steps 6, 7 and 8 about Fairness, Diversity and Robustness, see Figure 1, these were treated in a last summing-up discussion with the background knowledge that further design and alignment work was still going on. As concerns the SP toolbox in Table 3 brainstorming and stakeholder analysis were made use of as support for the various group deliberations, while cost-benefit analysis and multi-criteria analysis (analytic hierarchy process) were applied for the calculation work. The group concluded that the alternative to be recommended depended on the vision to be pursued so that adopting a SD vision should entail to base continued planning on P2 while adopting a BAU vision should similarly entail basing continued planning of the rail corridor on $\mathrm{P} 3$.

As the planning of the corridor has developed since the case work, both the visions behind P2 and P3 have been considered. However, the final project now almost ready for implementation resembles mostly P3. Overall the European-gauge standard will be applied, and furthermore it should be observed that the top speed for passenger trains now is up from $200 \mathrm{~km} / \mathrm{h}$ to $240 \mathrm{~km} / \mathrm{h}$, see (Rail Baltica Future Direct, 2018). 
For more detailed information about the Rail Baltica project planned to be constructed 2019-2026, see (Rail Baltica Documentation Library, 2018). For more detailed information about the demo case, see (Ambrasaite \& Leleur, 2014) (Leleur, 2017).

\section{DISCUSSION}

The Rail Baltica case in this context serves only to demonstrate the potential of applying SP. Although developed in a context of large transport infrastructure investment a more general application of SP is possible. A number of application examples including also such examples outside transport infrastructure planning are described in (Leleur, 2012, 2017). In these examples when combined all the aspects of SP are treated. Typically 4-5 of the OR methods in the toolbox have been applied with suitable and case-dependent soft and hard methods in combination.

Setting the focus on the group of participants in an SP decision conference it can be asserted that the group undergoes what may be termed 'accelerated learning' in relation to the understanding and 'solving' of the complex problem. Solving here is not to be understood in a conventional way but as a linking of complexity and simplicity represented by the accumulation of qualitative and quantitative knowledge at Step 9 in Figure 1. Perceiving the group as a 'body' this body evolves in relation to the actual problem by developing a certain kind of 'choice intelligence' as concerns complex strategic decision making, see (Leleur, 2012, 2014).

Fundamentally, SP draws on the five systems approaches in Table 1, which led to the five modes of enquiry, which again are behind the $2 \times 7$ soft and hard OR methods and the iterative nine-step process referred to as the SP wheel. With Table 1 a claim is made to encircle modern systems thinking for the use of better decision making when facing complex planning and strategic decision making. In addition to having inspired the specific modes of enquiry in SP, this table when presented to actual participants in an SP session also helps by forming a particular mind-set that is unique for each of the five systems approaches. By drawing on this uniqueness, in practice by invoking at different stages of the group process certain discourse/discussion modes, SP with its backdrop of the five systems approaches is found to be able to empower the understanding and creativity of the ongoing group deliberations; this is seen as necessary for dealing not least with complex problems.

The work on SP has grown on a foundation of the relevance of mixing methods as stated in Mingers and Gill (1997), Midgley (2000), Jackson (2000, 2003) and Rosenhead and Mingers (2001). A deviation from these foundational texts as regards the outline of SP is that complexity in SP is seen as a systems approach of its own and not as belonging to the functional domain. This demarcation is argued in Leleur $(2008 \mathrm{a}, 2012)$ with main references here given to the work of Luhmann (1995) and Morin (1992). In SP functionalist thinking is behind especially the Core Performance (CP) mode of enquiry, whereas complexity thinking informs especially the Robustness (RO) mode of enquiry, see Table 1. Thus functionalist thinking and complexity thinking - as experienced also in the group deliberations behind the cases where SP has been applied - have due to their highly different discourse domains led to different but valuable types of insights that can complement each other in the SP process.

Seeing the individual relevance of the five systems approaches as dependent not on any foundational theory per se but on the actual study purpose and context, SP appears as essentially multi-theoretical and multi-methodological (Midgley, 2011). Interpreting the five systems approaches as representative of different paradigms, SP furthermore appears as a multi-paradigmatic systemic practice and as an expression of what has been termed coherent pluralism (Bowers, 2014). 


\section{FINDINGS AND PERSPECTIVE}

This paper aims at presenting the idea behind systemic planning (SP) that modern systems thinking represented as five unique systems approaches can be operationalised into a generic framework that can assist complex planning and decision making. This framework referred to as systemic planning (SP) is based on research work carried out by the Decision Modelling Group at the Technical University of Denmark (DTU) over the last ten years fueled, among other things, by a number of Ph.D theses and a multitude of application examples.

Basically, SP sets focus upon wider holistic learning through a structured combining of different modes of enquiry (MOEs) under the labels: Core Performance, Wider Performance, Fairness, Diversity and Robustness. These MOEs constitute complementing explorative efforts empowered by soft and hard operations research (OR) methodology when applied in an iterative group process. Thus with their individual backdrop in a unique mind-setting systems approach, the MOEs seek to enable that overall a holistic perspective is adopted.

SP (with S for 'systemic') is not an alternative to systematic planning but it seeks to incorporate systematic thinking as part of a more comprehensive planning approach by applying both rational and arational (search-oriented, intuitive) thinking for planning and decision support (Dreyfus and Dreyfus, 1988) (Leleur, 2008b). If usual rational thinking linked to analytical decomposition expresses features of intelligent simplification thinking relating to hard OR methodology, we can see 'arationality' as expressing a kind of intelligent synthetic composing assisted by soft OR methodology.

That SP is worthwhile for complex planning and decision support is found to be justified by its actual use so far and the feedback obtained from the many people that have been involved in the group processes conducted over a decade. However, new applications will no doubt be valuable with provision of new insights about combining analytical and synthetic thinking for complex planning and decision making. Needless to say: with SP and complex decision making the proof of the pudding is in the eating ...

\section{REFERENCES}

Ambrasaite, I. \& Leleur, S. (2014). Managing Sustainable Transport Development: The Rail Baltica Case. International Conference on Social Science and Management (ICSSM 2014). Chicago, March 2014.

Bertalanffy, L. von (1973). General system theory - foundations, development, applications. Penquin books, London.

Bowers (2014). Developments in Critical Systems Theory: On paradigms and Incommensurability, $58^{\text {th }}$ Annual Meeting of the International Society for the Systems Sciences (ISSS).

Dreyfus, H.L. \& Dreyfus, S.E. (1988). Mind over machine. The Free Press Macmillan, New York.

Jackson, M.C. (2000). Systems approaches to management. Kluwer Academic, Berlin.

Jackson, M.C. (2003). Systems thinking: Creative holism for managers. Wiley, New York.

Leleur, S. (2008a). "Systems science and complexity: Some proposals for future development". Systems Research and Behavioral Science, 25(1): 69-79.

Leleur, S. (2008b). Systemic planning: Principles and methodology for planning in a complex world, Second edition. Polyteknisk, Copenhagen. (**) 
Leleur, S. (2012). Complex strategic choices: Applying systemic planning for strategic decision making. Springer, London. (*)

Leleur, S. (2014). "The Meaning of System: Towards a Complexity Orientation in Systems Thinking". International Journal of Systems and Society, 1(1): 21-34. (*)

Leleur, S. (2017). Green Decision Making: How Systemic Planning can support Strategic Decision Making for Sustainable Transport Development. E-book, Department of Management Engineering, Technical University of Denmark. (*) (**)

Leleur, S., Salling, K.B., Pilkauskiene, I. \& Nicolaisen, M.S. (2015). "Combining Reference Class Forecasting with Overconfidence Theory for Better Risk Assessment of Transport Infrastructure Investments". European Journal for Transport Infrastructure Research, 15(3): 362-375. (*)

Luhmann, N. (1995). Social systems. Stanford University Press, Palo Alto.

Midgley, G. (2000). Systemic intervention: Philosophy, methodology, and practice. Kluwer Academic, New York.

Midgley, G. (2011). "Theoretical Pluralism in Systemic Action Research". Systemic Practice and Action Research, 24: 1-15.

Mingers, J. \& Gill, A. (1997). Multimethodology. Wiley, Chicester.

Morin, E. (1992). The concept of system and the paradigm of complexity. In: Maruyama M. (Ed.) Context and complexity: Cultivating contextual understanding (pp. 125-138). Springer, Heidelberg.

Petkov, D., Petkova, O., Andrew, T. \& Nepal, T. (2007). "Mixing Multiple Criteria Decision Making with soft systems techniques for decision support in complex situations". Decision Support Systems, 43: 1615-1629.

Phillips, L.D. (2007). Decision conferencing. In: Edwards W., Miles R.F. \& von Winterfeldt D. (Eds.) Advances in decision analysis: from foundations to applications (pp. 375-399). Cambridge University Press, Cambridge.

Rail Baltica Future Direct (2018). Downloaded 5 September 2018 from:

http://www.railbaltica.org/wp-content/uploads/2017/04/R_B_buklets_21x21.pdf

Rail Baltica Library Documentation (2018). Downloaded 5 September 2018 from: http://www.railbaltica.org/about-rail-baltica/documentation

Rosenhead, J. \& Mingers, J. (2001). Rational analysis for a problematic world revisited. Wiley, New York.

Stowell, F. \& Welsh, C. (2012). The Manager's guide to systems practice: Making sense of complex problems. Wiley; Chicester.

(*): Available as download from https://www.researchgate.net/profile/Steen_Leleur

(**): Info on SP and download from http://www.systemicplanning.dk/ 